\title{
JARINGAN KEKERABATAN MATRILINEAL SEBAGAI MODAL SOSIAL PEREMPUAN CALEG DALAM PEMILU 2014
}

\author{
Indah Adi Putri ${ }^{1}$ \\ Received Article: 02 Nopember 2017 Reviewed Article: 18 Desember 2017 \\ Accepted Article: 20 December 2017
}

\begin{abstract}
This paper discusses the matrilineal kinship network used as social capital by women legislative candidate in the 2014 election. It is known that in Minangkabau which adheres to matrilineal kinship system, where there are ninik mamak and bundo kanduang that play a big role in the people. This is a social capital that can be used by women candidates as a strategy to get and gain voice support. The research was conducted on three women candidates who advanced for DPRD West Sumatra, two of them are petahana. The research method is qualitative with case study type. Data were collected by conducting in-depth interviews to women legislative candidates, and those involved in the process of winning candidates, such as ninik mamak and bundo kanduang.
\end{abstract}

Keywords : matrilineal kinship network, social capital, ninik mamak, bundokanduang

\begin{abstract}
Abstrak
Tulisan ini membahas tentang jaringan kekerabatan matrilineal yang digunakan sebagai modal sosial oleh perempuan caleg dalam Pemilu 2014. Diketahui bahwa di Minangkabau yang menganut sistem kekerabatan matrilineal, dimana terdapat ninik mamak dan bundo kanduang yang berperan besar dalam kaum. Hal ini menjadi modal sosial yang dapat digunakan oleh perempuan caleg sebagai strategi untuk mendapatkan dan meraih dukungan suara. Penelitian dilakukan terhadap tiga orang perempuan caleg yang maju untuk DPRD Sumatera Barat, dua diantaranya adalah petahana. Metode penelitian adalah kualitatif dengan tipe studi kasus. Data dikumpulkan dengan melakukan wawancara mendalam kepada perempuan caleg, dan orang-orang yang terlibat dalam proses pemenangan caleg seperti ninik mamak dan bundo kanduang.
\end{abstract}

Kata-kata Kunci: jaringan kekerabatan matrilineal, modal sosial, ninik mamak, bundokanduang

\section{A. PENDAHULUAN}

$\mathrm{M}$ enurut Richard Matland untuk menjadi anggota parlemen perem puan harus melewati tiga tahap: pertama, mereka harus memilih di antara mereka untuk maju ke pemilu; kedua, mereka harus menjadi calon anggota legislatif yang diajukan partai politik; dan ketiga, mereka harus terpilih lewat pemilu. Jika tahap pertama lebih mudah diselesaikan di antara perempuan sendiri, pada tahap kedua dan ketiga perempuan harus menyiapkan strategi karena terkait dengan sistem kepartaian dan pemilu (Matland, 2002:70).

Perempuan harus menyiapkan strategi karena terkait dengan sistem kepartaian dan

\footnotetext{
${ }^{1}$ Penulis adalah dosen tetap Jurusan IImu Politik FISIP Universitas Andalas, Email: Indahputri1981@yahoo.com
} 
pemilu. Di antara sejumlah persiapan yang mesti disiapkan oleh perempuan dalam mendapatkan nomor urut di partai adalah kemampuan untuk melakukan negosiasi dengan pengurus lainnya, Di samping itu rekam jejak dari masing-masing caleg juga menentukan. Pada tahapan pemilu, calon anggota legislatif harus mampu mendapa tkan kepercayaan dari masyarakat. Sejumlah strategi mesti disiapkan. Di antara strategi itu adalah kemampuan memanfaat kan jaringan keluarga besar (extended family), kemampuan memanfaatkan jaringan organisasi seperti Bundo Kanduang, organisasi sayap partai, majelis taklim dan lainnya. Itu semua adalah modal sosial yang besar, yang jika dimanfaatkan akan mampu menambah dukungan dan perolehan suara. Maka penelitian ini membahas bagaimana rekam jejak dari tiga anggota legislatif, bagaimana figuritas (yang memengaruhi kepercayaan pemilih) dapat memengaruhi keterpilihan dalam Pemilu.

Menurut Manon Tremblay, sistem pemilu, termasuk di dalamnya kuota perem puan dan partai politik memiliki potensi untuk memengaruhi proporsi perempuan dalam parlemen. Namun sistem pemilu tidak berdiri sendiri dalam memengaruhi proporsi perempuan tersebut. la harus berinteraksi dengan faktor budaya, sosio-ekonomi dan politik secara dinamis untuk dapat memengaruhi proporsi perempuan dalam parlemen. Faktor budaya menurut Trembley merujuk pada nilai, norma, kepercayaan dan prilaku yang menyokong suatu masyarakat beserta institusinya dan menjadi sandaran dari seluruh aspek kehidupan masyarakat tersebut. Agama, pendidikan dan cara pandang terhadap peran sosial yang berbasis gender adalah faktor-faktor budaya yang menjadi penentu dari proporsi perempuan dalam parlemen. Selain itu konsepsi kesetaraan antara perempuan dan laki-laki juga menjadi variabel yang mempengaruhi proporsi perempuan dalam parlemen di suatu negara (Tremblay, 2008 : 9).

Kehadiran norma dan kepercayaan umum dalam suatu kelompok masyarakat menjadi hal penting dalam bahasan modal sosial, karena di dalamnya terdapat seperangkat nilai-nilai yang diyakini bersa ma. Seperti di Minangkabau, masyara kat meyakini bahwa posisi perempuan adalah sebagai bundokanduang, yang menjadi penentu dan pembimbing dalam keluarga. Konsep modal sosial orang Minang mirip dengan apa yang dikemu kakan Putnam, dimana pergaulan adalah kunci keberhasilan ekonomi, budaya dan simbol status sosial.

Selanjutnya Robert D. Putnam menge mukakan perlunya pendefinisian jaringan yang dimaksud dalam modal sosial secara empiris, agar dapat menarik kesimpulan tentang bagaimana modal sosial dapat memengaruhi kebijakan atau masyarakat secara luas.

"Social capital, in short, refers to social connections and the attendant norms and trust. Who benefits from these connec tions, norms, and trust-the individual, the wider community, or some faction within the community-must be determined empirically, not definitionally (Putnam, 1995). (Pendeknya, modal sosial menga cu pada hubungan sosial dan kehadiran norma dan kepercayaan. Siapa yang mengambil keuntungan dari hubungan, kepercayaan dan norma-individu, ma syarakat yang lebih luas- harus ditentukan secara empiris, bukan definisional)"

Di dalam masyarakat Minangkabau Sumatera Barat, jaringan sosial antar kerabat perempuan dalam masyarakat Minangkabau sengaja dikembangkan dan dipelihara oleh perempuan dikarenakan jaringan tersebut memiliki makna strategis bagi mereka. Dari aspek ekonomi kerabat perempuan merupakan salah satu aset dan modal sosial yang dapat diandalkan untuk menjaga subsistensi maupun pemenuhan kebutuhan. Secara sosio-kultural jaringan sosial tersebut juga memiliki makna yang signifikan. Relasi dengan kerabat tidak hanya menunjukkan kepada orang luar bahwa sebuah keluarga/kaum merupakan kesatuan yang kompak. Lebih dari itu jaringan sosial merupakan sarana bagi individu untuk menunjukkan tanggung jawab moral dan tanggung jawab sosial. Sekaligus komitmen kesetiaan terhadap kerabat, bahwa apa yang diperoleh seseorang sesungguhnya tidak pernah terlepas dari bantuan kerabat. Secara politis jaringan sosial antar kerabat perempuan sengaja 
dikembangkan dikarenakan perempuan menyadari bahwa hubungan sosial mereka dengan kerabat laki-laki sangat terbatas. Hanya dengan bekerja sama dengan kerabat perempuan yang lain mereka bisa menaikkan posisi tawar menawar mereka bahkan mungkin dapat "menundukkan" kerabat laki-laki (Jendrius, 2000: 121). Artinya politik bagi perempuan Minang bukan hanya sekadar mengejar simbolik, ekonomi dan budaya, tetapi menggunakan semuanya itu untuk kepentingan modal sosial agar jaringan kekerabatan menjadi semakin kuat. Inilah yang dibuktikan dalam penelitian ini.

Berbeda dengan konsep modal sosial yang dijumpai dari studi Putnam di Sicilia, dimana jaringan keluarga dimanfaatkan untuk gerakan organisasi mafia. Jaringan keluarga di Minangkabau berasal dari keluarga inti meluas ke keluarga besar (extended family), dan dimanfaatkan untuk mendapatkan dukungan suara. Meskipun politik perempuan dilandasi ikatan kekerabatan, tetapi berbeda dengan politik klienship atau ikatan patron klien yang melahirkan ketergantungan. Terdapat logika modal dalam politik perempuan Minang serta menempatkan politik sebagai sesuatu yang sifatnya personal.

Pelaksanaan pembangunan politik untuk mewujudkan demokrasi modern didasarkan pada teori modernisasi yang cenderung mengabaikan relatifitas nilai sosial dan budaya. Penelitian ini menyajikan model demokrasi politik modern yang bisa mengakomodasi nilai sosial dan budaya masyarakat melalui strategi politik perem puan Minang dalam memenangkan kursi DPRD Sumbar melalui pelaksanaan demo krasi perwakilan. Strategi yang digunakan menggambarkan adanya nilai-nilai sosial dan budaya dalam masyarakat. Penelitian ini menjadi penting untuk melihat keterkaitan antara faktor budaya dan modal sosial yang dimiliki oleh caleg perempuan dalam mendapatkan dukungan dan meraih suara.

Pada penelitian ini yang diteliti adalah tiga perempuan anggota DPRD Sumatera Barat, yang dipilih secara sengaja, dimana dua orang adalah petahana dan satunya lagi caleg yang berhasil meraih suara paling banyak walaupun muncul dengan nomor urut besar. Pemilihan dua orang caleg petahana dengan asumsi bahwa mereka sudah memiliki jaringan yang luas dan memiliki strategi yang berbeda dengan caleg yang baru maju. Caleg petahana adalah Endarmy dan Siti Izzati Aziz. Sedangkan caleg peraih suara terbanyak diantara caleg perempuan terpilih adalah Marlina Suswati.

Robert Putnam mendefinisikan modal sosial sebagai fitur kehidupan sosial yang terdiri dari jaringan, norma dan keper cayaan, yang memungkinkan para pesertanya bertindak secara bersama untuk mencapai tujuan bersama. Modal sosial menjembatani masyarakat dalam kerjasama dan mengurangi perpecahan sosial. Keanggotaan jaringan dan seperangkat nilai bersama menjadi inti dari konsep modal sosial.

"Features of social life-networks, norms and trust-that enable participants to act together more effectively to pursue shared objectives..to the extent that norms, networks and trust link subtantial sectors of the community and span underlying social cleavages-to the extent that social capital is of a bridging short- then the enhanced cooperation is likely to serve broader interest and to be widely welcomed (Putnam, 1995). (fitur jaringan kehidupan sosial, norma dan kepercayaan - yang memungkin kan peserta untuk bertindak bersama secara lebih efektif untuk mencapai tujuan bersama. untuk batas-batas norma, jaringan, dan hubungan kepercayaan antara sektor subtantial masyarakat dan membentang pada perpecahan sosial yang mendasar sejauh Modal sosial bersifat menjemba tani-maka kerja sama yang disempurnakan cenderung akan mela yani kepentingan yang lebih luas dan disambut secara luas)"

Modal sosial mengacu pada hubungan sosial dengan kehadiran norma dan kepercayaan. Siapa yang diuntungkan dari hubungan ini harus ditentukan secara empiris, tidak definisional. Modal sosial dalam pengertian ini berkaitan erat dengan partisipasi politik dalam arti konvensional, namun hal ini tidak identik. Partisipasi politik mengacu pada hubungan kita dengan lembaga-lembaga politik. Modal sosial 
mengacu pada hubungan kita dengan satu sama lain. Putnam menyebutnya sebagai "civic engagement". Teori modal sosial mengandaikan bahwa secara umum sema kin kita berhubungan dengan orang lain, semakin kita mempercayai mereka dan sebaliknya. Kepercayaan sosial dan keter libatan masyarakat berkorelasi kuat.

\section{"I use the term "civic engagement" to refer to people's connections with the life of their communities, not merely with politics. The theory of social capital presumes that, generally speaking, the more we connect with other people, the more we trust them, and vice versa. At least in the contexts I have so far explored, this pre-sumption generally turns out to be true: social trust and civic engagement are strongly correlated (Putnam, 1995: 665) \\ (Saya menggunakan istilah "ikatan pribadi" untuk merujuk pada hubungan orang-orang dengan kehidupan komunitas mereka, tidak hanya dengan politik. Teori modal sosial mengasumsikan bahwa, secara umum, semakin kita terhubung dengan orang lain, semakin kita mempercayainya, dan sebaliknya. Paling tidak dalam konteks yang selama ini saya jelajahi, praduga ini pada umumnya ternyata benar: kepercayaan sosial dan keterlibatan masyarakat berkorelasi kuat)."}

Norma mendasari kepercayaan sosial karena dapat menyebabkan harga transaksi menjadi sedikit dan memfasilitasi kerjasama. Norma membutuhkan apa yang disebut reaksi timbal balik (Reciprocity). Reciprocity ada dua; ada yang disebut seimbang ada yang disebut umum. Reciprocity seimbang menghadirkan pertukaran timbal balik yang seimbang, misalnya pertukaran kado antar teman. Reciprocity umum, adalah pertuka ran yang berlangsung secara berkelanjutan, contohnya dalam persahabatan jika seseorang memberi belum tentu dibalas pada waktu itu juga, tetapi bisa dibalas pada waktu yang lain.

"Norms such as those that undergrid social trust evolve because they lower transaction costs and facilitate cooperation. The most important of these norms is reciprocity. Reciprocity is of two sorts, sometimes called balanced and generalized. Balance reciprocity refers to simultaneous exchange of items of equivalent value. Generalized reciprocity refers to a continuing relationship ofe exchange that is at any given time unrequited or imbalanced (Putnam, 1993: 172).

(Norma-norma seperti kepercayaan sosial berkembang karena menurunkan biaya transaksi dan memfasilitasi kerja sama. Yang paling penting dari normanorma ini adalah hubungan timbal balik. Hubungan timbal balik mengacu pada pertukaran item secara simultan de ngan nilai ekuivalen. Hubungan timbal balik umum mengacu pada hubungan berkelanjutan pertukaran yang pada waktu tertentu tidak berbalas atau tidak seimbang)"

Menurut Fukuyama, kepercayaan (trust) adalah harapan yang timbul dalam masyarakat dari prilaku yang teratur, jujur dan kooperatif, berdasarkan norma-norma umum bersama. lanya dapat terbentuk dari kelompok kecil dalam masyarakat seperti keluarga, sampai kelompok yang besar seperti negara.

"Trust is the expectation that arise within community of regular, honest and cooperative behavior, based on commonly shared norms, on the part of other members of that community. social capital is capability that arise from the prevalence of trust in a society or in certain parts of it. it can be embodied in the smallest and most basic social group, the family, as well as the largests of all groups, the nation and all the other group in between (Fukuyama, 1995). (Kepercayaan adalah harapan yang muncul dalam komunitas perilaku reguler, jujur dan kooperatif, berdasarkan norma bersama, dari anggota masyarakat lainnya. Modal sosial adalah kemam puan yang timbul dari prevalensi kepercayaan pada masyarakat atau di bagian-bagian tertentu. Hal itu dapat diwujudkan dalam kelompok sosial 
terkecil dan paling dasar, keluarga, dan juga kelompok terbesar, semua bangsa dan semua kelompok lainnya di antaranya)."

Modal Sosial pada akhirnya didasarkan pada nilai sosial spesifik, yaitu sebuah konsep normatif dan bukan sekedar diskripsi objektif mengenai perilaku manusia. Kekuatan kunci analisa modal sosial berada pada analisa normatif yang lebih luas, yang lebih dari sekedar partisipasi dalam aktivitas kelompok, tetapi mencakup bentuk interaksi sosial sebagai sumber daya, yang tidak hanya sekadar material atau finansial tetapi juga sumber kekuasaan (Portes,1998:2 dalam Prayitno, 2004).

Perbedaan mendasar modal sosial dari modal-modal lainnya, adalah bahwa modal sosial bukanlah milik individu, tetapi muncul sebagai hasil dari hubungan individu, sedangkan modal-modal lainnya dapat menjadi milik individu. Modal sosial dapat terwujud di dalam kelompok sosial yang paling kecil, seperti keluarga, tetapi dapat juga terwujud dalam kelompok sosial yang paling besar seperti negara. Modal sosial diciptakan dan ditransmisikan melalui mekanisme budaya, seperti tradisi, ke biasaan-kebiasaan. Komunitas yang me miliki mekanisme pewarisan modal sosial substansial dalam bentuk aturan-aturan, biasanya menjadi komunitas dengan jaringan sosial kuat yang memungkinkan kerjasama sukarela. Kerjasama sukarela ini biasanya tercipta, bila tingkat partisipasi yang setara dan adil (equal participation) di dalam komunitas sudah terwujud (Lubis, 1999:55 dalam Prayitno, 2004).

Penelitian ini melihat modal sosial yang digunakan oleh perempuan caleg dari penggunaan jaringan, berupa jaringan ke organisasi masyarakat dan jaringan kekerabatan matrilineal. Penelitian ini juga melihat bagaimana pola kerja perempuan caleg dalam struktur budaya masyarakat Sumatera Barat, dalam membangun kepercayaan dan penggunaan norma-norma yang ada seperti kepercayaan masyarakat terhadap ninik mamak, dan bundokanduang.

\section{B. METODE PENELITIAN}

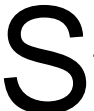
esuai dengan judulnya, penelitian ini termasuk dalam kategori penelitian kualitatif yang bersifat deskriptif analisis. Jenis penelitian ini merupakan studi kasus, sebab fokus permasalahan meru pakan sistem yang terintegrasi dan mengikat. Studi kasus bertujuan untuk mendeskripsikan unit analisa secara intensif dan menganalisa kasus tersebut secara mendalam. Data primer diperoleh dari wawancara mendalam (indepth interview) dengan menggunakan pedoman wawan cara. untuk itu disiapkan catatan lapangan yang berguna untuk memudahkan peneliti mencatat setiap fenomena dan data yang didapatkan. Wawancara juga memung kinkan peneliti mendapat kedalaman dan kelengkapan informasi (Creswell, 2002; Danim, 2002 : 35). Selain itu juga digunakan data sekunder dari dokumen arsip dan jurnal ilmiah lainnya. Diantara para informan adalah para tokoh perempuan caleg, ninik mamak, bundokanduang, dan pengurus partai. Lokasi penelitian ini adalah di Sumatera Barat.

\section{HASIL DAN PEMBAHASAN}

$\mathrm{R}$ uang lingkup modal sosial adalah batasan yang diberikan dalam melakukan analisis terhadap modal sosial. Sebagaimana yang dikatakan dalam teori modal sosial integratif bahwa ada tiga tingkatan analisis modal sosial, yaitu mikro, meso dan makro.

Analisis modal sosial di level mikro biasanya dihubungkan dengan definisi modal sosial yang diberikan Putnam. Dimana Putnam mendefinisikan modal sosial sebagai bentuk dari organisasi sosial seperti jaringan individual atau keluarga, yang berbaur dengan norma dan nilai-nilai yang membentuk eksternalitas bagi masyarakat secara keseluruhan. (features of social organization, such as networks of individuals or household, and the associated norms and values, that create externalities for the community as a whole) (Putnam dalam Grotaert dan Bastelaer, 2001). Eksternalitas yang dieksplorasi adalah hasil dari hubungan sosial yang terbentuk berdasarkan jaringan individu, keluarga, yang berkorelasi dengan norma dan nilainilai dalam masyarakat. Secara umum eksternalitas yang terbentuk dari proses politik calon legislatif dalam Pemilu 2014 bersifat positif, karena hanya berbentuk dukungan dan pemberian suara kepada 
perempuan caleg. Hal ini merupakan salah satu keuntungan dari modal sosial yang ditanamkan oleh individu caleg dalam waktu yang panjang.

Dalam penelitian ini ruang lingkup analisa modal sosial berada pada dimensi mikro, karena unit analisisnya adalah individu yaitu perempuan calon legislatif. Modal sosial terwujud dalam kelompok sosial yang paling kecil, seperti keluarga dan organisasi masyarakat. Fokusnya adalah pada hasil modal individu, tetapi ia tetap mempertimbangkan dalam konteks struktur sosial tertentu. Dimana terlihat dari aktivitas-aktivitas yang dilakukan oleh caleg di dalam struktur organisasi sosial yang diikutinya, dan ikatan pribadi yang terbentuk dalam keluarga.

Fokus analisis ada pada potensi individual dalam memobilisasi sumberdaya melalui jaringan sosial, pengalaman individu caleg dengan aktivitas sehari-hari. Penelitian ini memperlihatkan bahwa terda pat sejumlah potensi yang dimiliki oleh caleg perempuan Sumatera Barat, yaitu kede katan dengan masyarakat melalui organisasi sosial dan kedekatan dengan ninik mamak dan bundo kanduang serta keluarga besar yang terikat dalam jaringan kekerabatan matrilineal.

Pada pemilu legislatif Sumatera Barat tahun 2014, Siti Izzaty Aziz merupakan salah satu caleg yang terpilih dalam pemilu legislatif. Dalam pemilu legislatif tahun 2014 di sumatera barat, Siti Izzati Aziz maju sebagai petahana yang mewakili partai Golkar. Petahana adalah orang-orang yang menjabat sebelumnya dan mencalonkan lagi pada pemilihan berikutnya. Sebagai seorang petahana, Siti Izzati Aziz tentunya telah memiliki basis-basis suara yang sudah didapatkannya ketika mencalonkan diri pada pemilihan umum sebelumnya. Dengan sudah memiliki modal sebagai seorang petahana, maka dalam kampanye Siti Izzati Aziz mampu mendekati masyarakatnya karena sebelumnya ia sudah dikenal oleh masyarakatnya.

Dalam menghadapi pemilu tahun 2014 lalu, Siti Izzaty Aziz tentunya sudah memiliki modal sosial untuk membangun jaringanya. Dimana Siti Izzaty Aziz dapat memanfaatkan jaringan yang ia miliki sebelumnya agar mau membantu Siti Izzati Aziz dalam menghimpun suara. Adapun cara yang dilakukan Siti Izzati Aziz adalah dengan memanfaatkan jaringannya di beberapa organisasi yang pernah ia lakoni sebelumnya.

"dahulunya dimulai dari SMA, uni sudah mulai aktif di organisasi. Begitu juga semasa kuliah uni juga aktif beror ganisasi seperti ikut HMI, Fatayat NU, dan KNP. Sehingga ketika lulus kuiah uni ingin berbuat untuk masyarakat, makanya ingin masuk dalam sistem ini, dan organisasi uni dulu mau membantu uni untuk mengapai tujuan uni (Wawancara dengan Siti Izzati Aziz, 13/3/2017)"

Dari pernyataan Siti Izzati Aziz diatas, dapat dilihat dalam menghadapi pemilu tahun 2014 lalu Siti Izzati Aziz sudah memiliki modal, dimana perjalanan pendidikan Siti Izzaty Aziz dilaluinya dengan mengikuti organisasi-organisasi. Melalui organisasi-organisasi yang diikuti Siti Izzaty Aziz semenjak ia berada di sekolah menengah atas hingga di bangku kuliah tentunya memberikan pengalaman yang banyak untuk dirinya. Dengan pengalaman yang sudah ia pelajari dengan mengikuti organisasi-oraganisasi tersebut, itu merupakan suatu modal yang ia miliki dalam dirinya sendiri untuk menghadapi masya rakat, tentu ini juga berkaitan dengan bagaimana bisa ia mengerti tentang masyarakatnya. Siti Izzaty Aziz yang sudah mengikuti beberapa organisasi semenjak ia duduk di SMA hingga bangku kuliah, tentunya memiliki jaringan yang tentunya secara tidak langsung sudah ia bangun.

Menurut Coleman beberapa bentuk organisasi terkontruksi lebih cenderung mendorong modal sosial daripada bentuk organisasi terkonstruksi lain. Dalam esai yang membenarkan studi empirik awalnya tentang remaja, Coleman tertarik pada sifat antargenerasi ikatan religius:

"Organisasi keagamaan ada diantara organisasi yang masih tersisa di dalam masyarakat, di luar keluarga dan lintas generasi. Jadi, organisasi tersebut ada di antara organisasi yang di dalamnya modal sosial komunitas dewasa tersedia bagi anak-anak dan pemuda (Field, 2011:42)." 
Sebagaimana modal yang dimiliki Siti Izzaty Aziz yang mana ia memiliki pengalaman organisasi sebelumnya, tentu nya juga memiliki orang-orang yang bersedia membantunya untuk menghadapi pemilihan umum tahun 2014 lalu. Dimana orang-orang yang bersedia membantu Siti Izzati Aziz merupakan jaringan yang dimiliki Siti Izzaty Aziz. Sebagaimana yang diungkapkan oleh Siti Izzati Aziz bahwa orang-orang dari organisasi HMl ketika ia kuliah lalu, secara personal ikut membantu Siti Izzati Aziz untuk menghimpun suara di masyarakat.

Dari dukungan modal sosial, Siti Izzati Aziz yang sudah pernah menjabat menjadi anggota DPRD sebelumnya mencalonkan diri kembali pada Pileg 2014. Tentu Siti Izzati Aziz memiliki modal sosial yang mumpuni untuk memperoleh kursi DPRD provinsi Sumatera Barat untuk yang kedua kalinya. Berdasarkan hasil wawancara dengan Siti Izzati Aziz, ia mengatakan bahwa organisasi-organisasi yang dulu maupun sekarang yang ia geluti mendu kungnya meskipun tidak dikatakan secara gamblang oleh Siti Izzati Aziz.

"semasa uni kuliah dulu, uni tergabung dalam organisasi HMI, nah sekarang teman-teman dari $\mathrm{HMI}$ itu, tanpa diminta bergerak sendiri membantu uni, selanjutnya kelompok-kelompok Nah dliyin, tanpa sepengetahuan uni juga melakukan pergerakan membantu uni (Wawancara dengan Siti Izzati Aziz, 13/3/2017)."

Selanjutnya pengalaman Marlina Suswati dalam menjalani perannya sebagai anggota Suku tigo ninik selama proses pencalonannya sebagai caleg diakui oleh salah satu anggota keluarga besarnya sedikit banyak dipengaruhi oleh saudara laki-laki yang tinggal di kampung. Karena Marlina tidak tinggal di Sijunjung, maka peran sebagai anggota kaum lebih banyak disosialisasikan melalui kedekatan dengan saudara laki-laki. Anggota kaum yang mengenalkan Marlina melalui pertemuanpertemuan keluarga yang difasilitasi oleh saudara laki-laki (kakak).
"Jalur keluarga itulah yang paling penting. Jadi gini, menurut saya, kebe tulan kita tu kan punya keluarga besar, kita pakailah sistem kekeluargaan itu. Misal, di kampung sini saya punya saudara, nanti saudara saya yang ada dikampung tersebut punya saudara lagi di kampung lain.kita turun ke kampung itu. Lalu kita kan matrilineal nih. Matrili neal itu saya pikir ada juga bagusnya. Kan ada turunan nenek moyang kita tu darimana darimana, kita panggil itu. Kalau saya pikir gini, dengan sistem kekerabatan matrilineal, kita punya banyak jalur. Dari mamak ini ke mamak itu. Dari suku ini, kalau saya kan suku tigo niniak, ada Siek, Gantiang, Caniago. Jadi misalnya penghulu nya ada di suku gantiang, panditonya ada di suku caniago, manti nya di suku siek. Kan sudah ada tiga, kita kumpulkan semuanya, semuanya kan punya kerabat, keluarga-keluarga dekat kita kumpulkan semua. ada silaturahmi dengan ninik mamak (Wawancara dengan Marlina 13/3/2017)"

Hasil wawancara tersebut di atas memperlihatkan, bahwa keluarga memiliki peran penting dalam menyebarkan informasi tentang diri Marlina yang akan mencalonkan diri sebagai anggota legislatif. Nilai-nilai yang dianggap sama (seperti berasal dari keturunan yang sama, putra asli daerah) yang dimiliki sebagai sesama anggota kaum, berhasil membentuk ikatan pribadi (civic engagement) yang kuat selama proses kampanye dilakukan. Ditambah dengan kampanye melalui spanduk-spanduk, seleba ran, pembagian kaos semakin mendekatkan masyarakat dengan Marlina.

Keyakinan masyarakat yang mendu kung caleg karena alasan berasal dari keturunan yang sama atau hubungan famili adalah modal sosial kognitif. Bentuk modal sosial kognitif yaitu kepercayaan yang sifatnya subjektif diinstitusionalisasikan melalui kedekatan sebagai sesama anggota keluarga besar yang tersebar di berbagai nagari di daerah pemilihan.

"bapaknya adalah mamak bagi uni. Kenal sudah sejak lama. Beliau datang ke rumah minta tolong. Karena hubungan keluarga, dan alasan yang 
diberikan meyakinkan, uni siap jadi tim sukses (Wawancara dengan Reni, bako Marlina 14/6/2017)."

Peran sebagai anggota kaum atau Bundo Kanduang dalam kaum juga memudahkan transfer sikap dan keyakinan bagi Siti Izati Aziz. Menurutnya dengan kedekatan dengan ninik mamak memudah kannya melakukan sosialisasi diri tentang maksud dan tujuannya dalam pencalonan sebagai anggota legislatif.

"Dalam pertemuan ninik mamak uni katakan, bahwa kehadiran uni meminta doa restu dari ninik mamak untuk disampaikan kepada anak kemenakan, jika saya diberi amanah saya akan membangun kampung kita. Setelah itu baru para ninik mamak bergerak dengan anak kemenakannya (Wawan cara dengan Siti Izzati 22/5/2017)."

Ikatan pribadi yang terbentuk (civic engagement) atas dasar hubungan keluarga atau kedekatan dengan pemangku adat dalam kaum, telah menghubungkan indivi du-individu yang ada dalam social connectedness, sehingga memudahkan ca leg perempuan dalam proses kampanye politik mereka. Social connectedness yang terbentuk kemudian menjadi pembagian keyakinan dan kepercayaan di dalam masya rakat. Keyakinan bahwa sebagai sesama anggota keluarga akan memperjuangkan aspirasi mereka, dan kepercayaan bahwa sebagai sesama anggota kaum akan menepati janji jika terpilih menjadi anggota legislatif.

"kan ada falsafah orang minang. tagak kampuang mamaga kampuang, tagak nagari mamaga nagari, tagak bakaum mamaga kaum (kalau sama-sama satu kampuang, dibela, kalau sama sama satu nagari, dibela, kalau sama satu kaum, dibela) Logikanya kan seperti itu. Kalau mungkin dan patut. Apa salahnya. Baik omongannya dan kelembutannya bicara dengan masya rakat, bicara apa adanya, tanpa berjanji muluk-muluk, merupakan alat perekat lah dengan kami. Dia tidak berkampanye terbuka. Dia datang kerumah-rumah. Mendatangi tokoh- tokoh, bersilaturahmi. Dengan keadaannya yang seperti yang secara finansial tidak ada, membuat orang tergugah (Wawancara dengan Datuk Garang, Mamak Siti 20/7/2017)."

Prinsip berbagi informasi dan aksi kolektif modal sosial perempuan Minang dalam proses pencalonan menempatkan kepercayaan sebagai modal politik. Kepercayaan sebagai modal utama merupa kan pendorong kerjasama dalam kondisi pertarungan kandidat. Karena konsep anggota legislatif merupakan konsep public goods dalam analisis modal sosial. Terdapat konsensus bersama bahwa trust (keperca yaan) sebagai nilai universal menjadi standar umum dalam persaingan perebutan jabatan.

Gagasan sentral modal sosial adalah bahwa jaringan sosial merupakan aset yang sangat bernilai. Jaringan memberikan dasar kohesi sosial karena mendorong orang bekerja satu sama lain- dan tidak hanya sekedar dengan orang yang mereka kenal secara langsung- untuk memperoleh manfaat timbal balik (Field, 2011: 12)

Jaringan menjadi penting, karena saat tertentu kita membutuhkan dana, referensi dan lain sebagainya. Sebagaimana dikatakan John Field, dengan membangun hubungan dengan sesama, dan menjaganya agar terus berlangsung sepanjang waktu, orang mampu bekerja bersama-sama untuk mencapai berbagai hal yang tidak dapat mereka lakukan sendirian. Orang berhubungan melalui serangkaian jaringan dan mereka cenderung memiliki kesamaan nilai dengan anggota lain dalam jaringan tersebut. Ini berarti bahwa semakin banyak anda mengenal orang dan memiliki kesamaan cara pandang dengan mereka maka semakin kaya modal sosial anda (Field, 2011:1).

Kekerabatan adalah hubunganhubungan sosial yang terjadi antara seseorang dengan saudara-saudaranya atau keluarganya, baik dari jalur ayahnya maupun ibunya. Pusat sistem kekerabatan adalah keluarga, baik keluarga inti maupuan keluarga besar (extended family). Dalam keluarga terjadi interaksi peran-peran antar anggotanya dengan status yang berbeda (Mansur, 1988: 16-17), Jadi modal sosial berupa jaringan kekerabatan matrilineal 
adalah hubungan sosial yang dibentuk dari adanya keturunan dari garis ibu.

Peran bundo kanduang di Minang kabau termaktub dalam suatu ungkapan di tambo, merupakan sumber klasik sejarah Minangkabau. Bunyinya:

"limpapeh rumah gadang, umbun puruak pagangan kunci, amba puro aluang bunian, pusek jalo kumpulan tali, Sumarak di dalam kampuang, hiasan dalam nagari, nan gadang basa batua, kok iduik tampek banasa, kok mati tampek baniaik, ka unduangunduang ka madinah, ka payuang panji ka sarugo (Maradjo, dalam Iskandar 2014). (Limpapeh rumah besar, umbun puruk pegangan kunci, hambar pura alung bunian, pusat jala kumpulan tali, semarak di dalam kampung hiasan dalam nagari, yang besar besar bertuah, jika hidup tempat binasa, jika mati tempat berniat, ke undung-undung ke Madinah, ke payung panji ke surga)".

Perempuan sebagai limpapeh mengan dung makna yang prinsipil. Secara harfiah, limpapeh artinya tiang tengah yang menjadi penyangga bagi tiang-tiang lainnya dalam sebuah bangunan. Apabila tiang tengah ini ambruk, maka tiang-tiang lainnya ikut jatuh berantakan. Dalam konteks keluarga, terlihat betapa sentralnya posisi dan peran bundo kanduang sebagai pembimbing dan pendidik bagi anakanaknya serta anggota keluarga lainnya. Bundo kanduang bahkan memiliki tanggung jawab yang besar. Ungkapan umbun puruak pagangan kunci mengandung makna bahwa bundo kanduang adalah sosok wanita bijaksana, telaten dalam rumah tangga, pandai merawat penampilan diri, serta patuh pada suami. Pusek jalo kumpulan tali, berarti bahwa perempuan sebagai pengatur kehidupan rumah tangga. Baik jeleknya anggota keluarga ditentukan oleh ibu atau perempuan. la tempat suri teladan, tidak hanya bagi keluarga tetap juga masyarakat. Karena itu, ibu juga dituntut memiliki ilmu pengetahuan, terutama ilmu pengatahuan agama, sebagai bekal kehidupan anakanak. Ilmu itu didapatkan dengan cara belajar dan menuntut ilmu (Iskandar, 2014).
Berdasarkan penjelasan-penjelasan diatas, bahwasannya bundo kanduang memiliki peranan yang besar di tengah masyarakat. Dalam Pemilu 2014 lalu, pe rempuan caleg juga mengakui bahwa terdapat pengaruh bundo kanduang dalam memengaruhi anggota kaum tentang calon legislatif yang akan dipilih.

"kalau yang begitu besar perannya adalah etek Ety, saudara perempuan mama. Dia ikut mempersiapkan perte muan-pertemuan, melobby perem puan perempuan yang lain di kampung dan se kaum (Wawancara dengan Siti Izzaty 22/5/2017)"

Berdasarkan penjelasan Siti Izzaty Aziz diatas tergambar bahwa perempuan yang dituakan dalam kaum memiliki andil dalam mensukseskan keterpilihan perempuan caleg. Hal diatas terjadi karena adanya perubahan-perubahan yang terjadi di tengah masyarakat. sesuai dengan ungkapan pepatahnya "sakali aie gadang sakali tapian barubah " (sekali banjir, sekali tepian mandi berpindah, sekali musim betukar, sekali cara berganti). Artinya, orang Minangkabau menyadari bahwa setiap pola yang berkembang dan dikembangkan dalam kehi dupan masyarakat memiliki daya lentur terhadap perubahan. Ungkapan tersebut mengisyaratkan bahwa sebenarnya perubahan pada kehidupan masyarakat merupakan fenomena sosial yang wajar, karena setiap manusia mempunyai kepen tingan yang tak terbatas (Sismarni, tanpa tahun).

Dalam kekuasaan perempuan Minang kabau terlihat bahwa kekuasaan itu bukan suatu yang bersifat publik/formal/inpersonal tetapi the personal is political. Hal ini dapat diartikan sebagai setiap kehidupan personal seseorang secara langsung mempengaruhi dan dipengaruhi oleh apa yang terjadi lingkungan publiknya. Jocelyn A Scuut mengatakan bahwa sumber kekuasaan itu justru bukan semata-mata terletak di dunia publik, melainkan antar dunia personal dan publik saling mempengaruhi sehingga kekuatan privat atau personal pada giliran nya dapat merembes ke dunia publik, dari keluarga ke Negara (Idris, 2010).

Selain peranan Bundokanduang dalam mendukung perempuan caleg pada pemilu 
legislatif tahun 2014 lalu di provinsi Sumatera Barat, dalam menghadapi pemilu caleg perempuan juga memanfaatkan jaringan melalui tokoh-tokoh adat yang ada di daerahnya. Dimana kedudukan tokoh adat yakni ninik mamak dan alim ulama masih sangat berpengaruh di Minangkabau.

Peranan tokoh adat tersebut terbukti dengan apa yang dilakukan oleh Marlina Suswati yang menghadapi pemilu legislatif lalu dengan melakukan pendekatan kepada tokoh adat yang ada di daerahnya, berikut pernyataan Marlina Suswati dibawah ini:

\begin{abstract}
"di kampung sini saya punya saudara, nanti saudara saya yang ada dikampung tersebut punya saudara lagi di kampung lain. kita turun ke kampung itu. Lalu kita kan matrilineal nih. Matrili neal itu saya pikir ada juga bagusnya. Kan ada turunan nenek moyang kita tu darimana darimana, kita panggil itu. Kalau saya pikir gini, dengan sistem kekerabatan matrilineal, kita punya banyak jalur. Dari mamak ini ke mamak itu. Dari suku ini , kalau saya kan suku tigo niniak, ada siek, gantiang, caniago. Jadi misalnya penghulu nya ada di suku gantiang, panditonya ada di suku caniago, manti nya di suku siek. Kan sudah ada tiga, kita kumpulkan semuanya, semuanya kan punya kerabat, keluarga-keluarga dekat kita kumpulkan semua. ada silaturahmi dengan ninik mamak (Wawancara dengan Marlina Suswati, 13/3/2017)"
\end{abstract}

Berdasarkan penjelasan Marlina Suswati diatas, dapat simpulkan bahwa Marlina Suswati selaku caleg perempuan yang berasal dari kabupaten Sijunjung memanfaatkan sistem kekerabatan matrili neal yang ada di minangkabau. Dimana dengan memanfaatkan sistem kekerabatan ini memerikan keuntungan yang lebih, hal ini ditunjukkan dengan sistem kekabatan yang memiliki jaringan sosial yang luas ditengah masyarakat. Marlina Suswati ketika menghadapi pemilu legislatif tahun 2014 lalu, berusaha melakukan pendekatan kepada ninik mamak. Hal ini ini dikarenakan kedudukan ninik mamak dan alim ulama di tengah masyarakat minangkabau memiliki pengaruh yang besar. Melalui Ninik Mamak diharapkan bisa menghimpun suara dari masyarakat secara menyeluruh hingga ke anak kemenakannya.

Ninik mamak adalah laki-laki dari suatu kaum yang telah dituakan dan menjadi tempat: baiyo dan bamolah (bertanya dan bermusyawarah), walaupun dia masih muda, namun dituakan karena sifat-sifat mulia yang dipunyai mereka; apakah mereka alim ulama, cerdik pandai, pemuka masyarakat, petani, ataupun pejabat, makanya sering kita dengar sebutan di Minangkabau dalam pidato-pidato di depan masyarakat; sebutan ninik mamak, alim ulama, cerdik pandai, nan gadang basa batuah (yang besar serta bertuah). Ada ninik mamak pemangku adat, seperti: Imam chatib, pemuka agama, labai dan pandito, tugas tertentu, sebagai penghubung. Rang tuo adat adalah mamak-mamak yang sudah tua yang telah pensiun yang masih tetap dimintai pendapatnya dan dihormati (Idris, 2012) Yang mana peranan ninik mamak ini dalam kehidupan masyarakat tentunya memiliki peranan yang sangat penting.

Pada kasus Siti Izzati yang memiliki ikatan pribadi dengan mamak kaum contohnya, dimana ikatan dibangun atas dasar kesamaan nilai hidup dan budaya yaitu sama-sama satu kaum (Suku Sikumbang), memudahkan Siti untuk melakukan sosialisasi diri pada masa kampanye melalui bantuan Mamak tersebut. Proses pengenalan diri dilakukan sejak tahun 2004. Siti mendekatkan diri kepada tokoh-tokoh masyarakat dan alim ulama melalui mamaknya yang juga pengurus Lembaga Kerapatan Adat Alam Minang kabau (LKAAM) di Padang Pariaman.

"sebelum pemilu 2004 sudah mende kati tokoh-tokoh masyarakat. Dia menceritakan bagaimana keadaan finansialnya yang kurang memadai, yang akan maju sebagai caleg, Dengan apa adanya bu Siti berjalan mendekati hati tokoh tokoh masyarakat. Dia baca keadaannya yang minus. Dan dia ceritakan kondisinya sebagai caleg dari partai Golkar dari provinsi, dimana secara finansial tidak ada yang mendukung, la berhasil mungkin dari keterbu kaannya dengan tokoh tokoh masyarakat, yang menjadi modal utama ia maju setahap demi setahap dalam proses politik (Wawancara 
dengan Datuk Garang, Mamak Kaum Sikumbang, 20/7/2017)."

Ikatan pribadi yang terbentuk dari jaringan di dalam kaum memperlihatkan adanya gemenschaft atau solidaritas primor dial. Sama dengan kasus Marlina yang mengandalkan jaringan ke ninik mamak, agar mendapat pengaruh kepada anak dan kemenakan. Individu-individu yang berada pada posisi istimewa akan mempertahankan posisi mereka dengan menggunakan koneksi mereka dengan orang lain yang berkedudukan istimewa di dalam kaum.

Modal sosial memberi sumbangsih pada tindakan kolektif dengan meningkatkan biaya potensial bagi para pelaku politik, mendorong diperkuatnya norma-norma resiprositas; memfasilitasi aliran informasi, memasukkan informasi tentang reputasi para aktor; memasukkan keberhasilan upaya kolaborasi dimasa lalu; dan bertindak sebagai cetak biru bagi kerjasama di masa yang akan datang (Putnam, 1993a:173 dalam Field, 2011). Apa yang dilakukan Datuk Garang adalah contohnya, dimana dengan kedekatan selaku Mamak dengan Siti Izzati, walaupun dengan kondisi finansial yang minim, pada Pemilu 2014 ia kembali mendukung Siti dengan mengajak Siti datang ke pesantren-pesantren, bertemu dengan alim ulama, menyatakan maksud dan tujuan untuk menjadi anggota legislatif dengan visi misinya.

"saya bawa dia ke surau-surau, pesantren-pesantren, ke ulama-ulama yang ada. Sebenarnya belaskasihan orang ke bu Siti ini. (Wawancara dengan Datuk Garang, Mamak Kaum Sikumbang, 20/7/2017)"

Secara garis besar, wujud nyata modal sosial dalam masyarakat dapat digambarkan pada kesediaan hidup berdampingan satu sama lain. Suatu bentuk komunikasi bersama, interaksi antar individu yang mem buka kemungkinan campur tangan dan kepedulian individu terhadap individu yang lain. Bentuk ini mempunyai nilai positif karena masyarakat mempunyai keadilan sosial di lingkungannya. Modal sosial juga mewujud dalam budaya lokal, yang masih terpelihara erat di masyarakat, baik yang bersifat demokratis Maupun sebaliknya seperti budaya feodalisme. Banyak sekali nilai dan budaya lokal yang bercirikan kebersamaan, kerjasama dan hubungan sosial dalam masyarakat (Nurmalasari, 2011).

\section{KESIMPULAN}

$\mathrm{S}$ ehubungan dengan interaksi antara budaya dan proses politik dimana di Sumatera Barat terdapat Bundo kanduang, meskipun bundo kanduang memiliki peran dan kedudukan yang tinggi dalam sistem sosial budaya di minang kabau. Dalam menghadapi pemilihan umum, peranan dan kedudukan yang dimiliki oleh bundo kanduang tersebut tidak memiliki pengaruh yang besar dalam perolehan suara di tengah masyarakat. Dimana kedudukan dan peran yang tinggi yang dimiliki seorang bundo kanduang di dalam sistem sosial dan budaya, tidak dapat menjadi acuan untuk kemenangan dan keterwakilan perempuan di parlemen. Status bundo kanduang di Sumatera Barat tidak dapat menjadi jaminan keterwakilan perempuan di parlemen. Namun bundo kanduang dalam kaum berperan dalam melobby anak dan kemanakan untuk mendukung perempuan caleg.

Sistem kekerabatan matrilineal yang ada di tengah masyarakatnya, memberikan suatu keuntungan yang cukup baik dalam menghimpun masyarakat guna mendulang suara di tengah masyarakat tersebut pada pemilihan umum. Sistem kekerabatan Matrilineal dikenal sebagai sistem kekeraba tan yang kental. Dimana di Minang kabau mempunyai suku-suku yang dianut oleh masyarakatnya. Setiap suku memiliki ikatan yang baik sesama satu suku. Sehingga dalam setiap pemilu ataupun pilkada, setiap calon atau kandidat memanfaatkan setiap celah yang dimiliki untuk mendekati masyarakat melalui mamak kaum atau ninik mamak nya atau tokoh adat setempat. Peranan tokoh adat di Minangkabau masih diperhitungkan oleh masyarakatnya. Sehing ga dengan adanya sistem Matrilineal tersebut, terbentuk jaringan-jaringan yang dapat memperluas basis suara yang akan dicapai. 


\section{DAFTAR PUSTAKA}

Creswell, John W, 2002, Research Design, Qualitative \& Quantitative Approaches, Jakarta: KIK Press

Danim, Sudarwan, 2002, Menjadi Peneliti Kualitatif, Bandung : Pustaka Setia

Field, John, 2011, Modal Sosial, Bantul: Kreasi Wacana

Fukuyama, Francis, 1995, Trust, The Social Virtues and the Creation of Prosperity, USA: The Free Press

Grotaert, Christiaan and Bastelaer, Thierry, 2001, Understanding and Measuring Social Capital, Social Initiative Working Paper No.24. April

Idris, Nurwani, 2010, Perempuan Minangkabau dalam Politik, dalam Jurnal Humaniora. Vol 22. No.2 juni 2010

Idris, Nurwani, 2012, Kedudukan Perempuan dan Aktualisasi Politik dalam Masyarakat Matrilineal Minangkabau. Dalam Jurnal Kebudayaan dan Politik volume 25 nomor 2

Iskandar, Israr, 2014, Perempuan dan Mitos Demokrasi Minang. Analisis Sejarah, Volume 5, No. 1, Labor Sejarah, Universitas Andalas.

Jendrius, 2000, "Jaringan Sosial Antar Kerabat Perempuan dalam Masyarakat Marilineal Minangkabau Perkotaan, Tesis Koleksi Perpustakaan Universitas Indonesia.

Mansur, M.Yahya, 1988, Sistem Kekerabatan dan Pola Pewarisan, Jakarta: PT Pustaka Grafika Kita

Matland, Richard E, 2002, "Meningkatkan Partisipasi Politik Perempuan : Rekrutmen Legislatif dan Sistem Pemilihan" dalam Julie Ballington, Perempuan Parlemen Bukan Sekedar Jumlah, Jakarta: International Idea

Nurmalasari, Dewi, 2011, Modal Sosial Calon Legislatif Perempuan Dalam Pemilu 2009 di Kabupaten Indramayu dalam Jurnal Inspirasi Volume 1 Nomor 2 Februari

Prayitno, Ujianto Singgih , 2004. "Modal Sosial dan Ketahanan Ekonomi Keluarga Miskin", Disertasi Koleksi Perpustakaan Universitas Indonesia

Putnam, Robert D, 1995, "Tuning In, Tuning Out: The Strange Disappearance of Social Capital in America", dalam Jurnal Political Science and Politics, Vol.28 No.4, APSA,Desember

Putnam, Robert D, 1993, (ed) Making Democracy Work, New Jersey : Princenton University Press,

Sismarni, (Tanpa tahun), Perubahan Peranan Bundo Kanduang dalam Kehidupan Minangkabau Modern, Jurnal Ilmiah Kajian Gender

Tremblay, Manon, ed, 2008, Women and Legislative Representation : Electoral Systems, political parties and sex quotas, New York : Palgrave MacMillan 